\title{
Komunikasi Publik di Masa Pandemi Covid-19
}

\author{
Ibnu Hajar Sainuddin \\ Sekolah Tinggi Agama Islam Darud Da'wah wal Irsyad Kota Makassar \\ Email: dewaibnuhajar@gmail.com
}

\begin{abstract}
Abstrak
Wabah Covid-19 merupakan jenis penyakit virus yang sangat berbahaya dan proses penularannya begitu cepat kepada manusia. Sejak ditemukan di Wuhan, virus ini telah banyak memakan korban bahkan sampai berujung pada kematian. Sejak virus ini masuk ke Indonesia, terjadi banyak perdebatan dikalangan masyarakat. Pemerintah selaku pengambil kebijakan mempunyai tanggung jawab dalam memberikan informasi kepada publik terkait bahaya yang diakibatkan oleh virus tersebut. Disisi lain, pemerintah juga harus memberikan edukatif kepada masyarat untuk mematuhi protokol Kesehatan. Wabah Covid-19 juga berdampak pada ekonomi dan sosial bagi masyarakat bahkan sampai terjadi pengangguran akibat perusahaan bangkrut akibat dari wabah Covid-19.
\end{abstract}

\section{Pendahuluan}

Di masa pandemi Covid-19 telah terjadi banyak informasi dan berita bohong bertebaran (Musaffak, M., \& Setiawan, A. 2020, October). Dengan adanya berita bohong terkait Covid-19 menyebabkan ketakutan yang berlebihan di masyarakat (Rayani, D., \& Purqoti, D. N. S. (2020).. Di sisi lain dibutuhkan kewaspadaan baik secara pribadi maupun secara kelompok dalam mencegah terjadinya penularan virus tersebut (Nurrahman, A. (2020).

Wabah Covid-19 merupakan peristiwa menyebarnya penyakit virus (Yunus, N. R., \& Rezki, A. (2020). Dalam bahasa medis, Covid-19 adalah Corona virus disease 2019 yang merupakan virus jenis baru dan para ilmuan memberikan nama SARS CoV-2 (Supriatna, E. (2020). Wabah Covid-19 pertama kali ditemukan di Tiongkok China tepatnya di Kota Wuhan provinsi Hubei.

Sejak ditemukan wabah virus tersebut, mengakibatkan banyaknya korban yang tertular bahkan sampai pada kematian (Putri, A. (2020). World Health Organization (WHO) sebagai organisasi tertinggi di bidang kesehatan yang dinaungi langsung oleh PBB menetapkan virus Covid-19 sebagai status pandemi atau bencana dunia (Buana, D. R 2020). World Health Organization (WHO) menetapkan status pandemi pada tanggal 11 Maret 2020. 
Oleh karena itu, maka pemerintah semestinya mengambil langkah langkah taktis atau melakukan penyampaian informasi kepada publik terkait berita atau informasi yang berkaitan dengan Covid-19.

\section{Pembahasan}

Virus Covid-19 merupakan virus yang sangat berbahaya (Nasution, N. H., \& WIJAYA, W. (2020). Dikatakan berbahaya karena proses penularannya begitu cepat antara manusia ke manusia (Setyawati, 2020). Wabah Covid-19 mudah menulari kepada siapapun ketika terjadi proses bersentuhan antar manusia atau bisa jadi penularan melalui droplet.

Sampai saat sekarang ini, virus Covid-19 belum ditemukan obatnya (Susanto, 2020). Negara maju maupun berkembang berbondong-bondong untuk menciptakan obat atau vaksin Covid-19 yang sedang melanda dunia. Bahkan dari proses pengembangan virus tersebut negara-negara maju bahkan negara berkembang berusaha menciptakan vaksin dengan target sesegera mungkin.

Sejak wabah Covid-19 melanda dunia, banyak terjadi kesimpangsiuran informasi bahkan tersebar informasi bohong atau hoax (Noor, 2018). Tidak sedikit dari berita tersebut dimanfaatkan oleh orang yang tidak bertanggung jawab untuk mendapatkan keuntungan (Mahadi, 2020). Dari berita tersebut bahkan berujung kepada proses hukum diakibatkan dari berita bohong atau hoax

Sejak Covid-19 muncul dari Wuhan dan menyebar ke seluruh dunia, data mencatat total kasus covid-19 di dunia yang terkonfirmasi sebanyak kurang lebih hampir mencapai 30 juta kasus (Alwi, 2020). Penyebaran virus Corona secara global akan terus bertambah dari hari ke hari dan waktu ke waktu

Di masa pandemi Covid-19 saat ini dibutuhkan peran pemerintah dalam menangani kasus penyebaran virus Covid-19. Salah satu yang menjadi tolok ukur pemerintah dalam menangani kasus tersebut adalah melalui komunikasi publik (Siti Maryam, 2017). Pemerintah semestinya dalam menyampaikan informasi kepada publik harus sesuai dengan pemahaman masyarakat secara umum.

Dalam menyampaikan informasi kepada publik, selain mengimbau masyarakat untuk memutus rantai penyebaran virus pemerintah juga memberikan edukasi kepada masyarakat terkait pencegahan penyebaran virus Corona (Hasrul, 2020). Informasi kepada publik sama halnya kakwah juga memberikan informasi dan himbauan kepada masyarakat (mad'u) (Sainuddin, I. H., S. (2020, July 19). 
Persepsi publik tentang Covid-19, masyarakat belum tahu dalam bersikap kemudian pemerintah semestinya mampu memberikan solusi (iwandono, I. S., Setiawan, H., \& Oktaviyanti, I. (2020). Dengan kejadian ini, dari segi ekonomi pendapatan masyarakat menjadi menurun drastis bahkan sampai kehilangan pekerjaan. Beberapa Perusahaan yang terkena dampak dari Covid-19 mengambil langkah dengan memberhentikan sementara para karyawannya karena tidak mampu menggaji akibat menurunnya produksi. Oleh karena itu tugas pemerintah harus membantu dan menyelesaikan masalah masyarakat terkhusus pada masalah ekonomi dan sosial.

Akibat dari Covid-19 ditambah dengan komunikasi publik pemerintah yang kurang efektif sehingga masyarakat menjadi dilema (Prasetya, 2020). Dari dilema tersebut terdapat dua pilihan antara yaitu mencari nafkah dengan resiko terpapar Covid-19 atau berdiam diri di rumah tetapi tidak mendapatkan kan apa-apa. Begitu pula aktivitas dakwah, terjadi dilema bagi para dai antara melalui tatap muka di masa new normal (Sainuddin, 2020).

Dari kejadian ini pemerintah juga menjadi dilema dan pilihan yang sulit antara menyelamatkan ekonomi atau kesehatan publik. Untuk menghentikan penularan Covid-19 publik harus menjalankan protokol kesehatan secara ketat dan menerapkan aturan-aturan yang mengikat terhadap perilaku publik serta taat dan patuh. Jika publik taat dan patuh, maka akan secara otomatis masyarakat mampu beradaptasi dengan kehidupan yang baru dalam tatanan hidup new normal.

Dengan demikian, artikel ini menunjukkan bahwa komunikasi publik di masa Covid-19 sangatlah penting karena berkaitan dengan informasi yang akan disampaikan kepada masyarakat dengan perbandingan (Muhawarman, A., Ayuningtyas, D., \& Misnaniarti, M. (2017) yang membahas Formulasi Kebijakan Komunikasi untuk Pelaksanaan Program Pembangunan Kesehatan, (Laksmiwati, I., \& Lukitawati, L. (2020) yang hanya membahas komunikasi public Menteri Kesehatan Terawan, (Syaipudin, 2020) yang membahas tentang Peran Komunikasi Massa di Tengah Pandemi Covid-19 (Studi Kasus di Gugus Tugas Percepatan Penanganan Covid-19 Kabupaten Tulungagung). Oleh karena itu, komunikasi public di masa Covid-19 yang penting, disisi lain memberikan informasi kepada masyarakat terkait perkembangan Covid-19 juga memberikan informasi edukasi kepada masyarakat dalam mencegah terjadi penularan dan memutus mata rantai penyebaran Covid-19 di masyarakat dengan menerapkan protokol Kesehatan 


\section{Kesimpulan}

Pemerintah dalam menyampaikan informasi kepada publik di sisi lain memberikan himbauan juga harus memberikan edukasi terkait pencegahan penularan Covid-19. Kika komunikasi publik pemerintah efektif, maka masyarakat juga akan mengikuti imbauan pemerintah dengan menerapkan protokol kesehatan yang ketat sehingga proses penyebaran Covid-19 dapat berkurang.

\section{Daftar Pustaka}

Alwi, V. A. P. (2020). makalah penyakit menular dan covid-19.

Buana, D. R. (2020). Analisis Perilaku Masyarakat Indonesia dalam Menghadapi Pandemi Virus Corona (Covid-19) dan Kiat Menjaga Kesejahteraan Jiwa. Salam: Jurnal Sosial dan Budaya Syar-i, 7(3), 217-226.

Hasrul, M. (2020). Aspek Hukum Pemberlakuan Pembatasan Sosial Berskala Besar (PSBB) Dalam Rangka Penanganan Corona Virus Disease 2019 (Covid-19). Jurnal Legislatif, 385398.

Jiwandono, I. S., Setiawan, H., \& Oktaviyanti, I. (2020). PERSEPSI MAHASISWA TERHADAP POLITISASI CORONA VIRUS DISEASE (COVID-19). Jurnal Ilmiah Dinamika Sosial, 4(2), 286-299.

Laksmiwati, I., \& Lukitawati, L. (2020). KOMUNIKASI PUBLIK MENTERI KESEHATAN TERAWAN. MEDIA BINA ILMIAH, 14(12), 3581-3590.

MAHADI, A. (2020). Praktik Hegemoni Dalam Novel Orang-Orang Proyek Karya Ahmad Tohari (Kajian Hegemoni Gramsci). BAPALA, 7(1).

Muhawarman, A., Ayuningtyas, D., \& Misnaniarti, M. (2017). Formulasi Kebijakan Komunikasi untuk Pelaksanaan Program Pembangunan Kesehatan. Media Kesehatan Masyarakat Indonesia Universitas Hasanuddin, 13(2), 97-106.

Musaffak, M., \& Setiawan, A. (2020, October). Membaca kritis sebagai salah satu langkah antisipasi misinformasi di masa pandemi. In Prosiding Seminar Nasional Bahasa dan Sastra Indonesia (SENASBASA) (Vol. 4, No. 1). 
Nasution, N. H., \& WIJAYA, W. (2020). MANAJEMEN MASJID PADA MASA PANDEMI COVID 19. Yonetim: Jurnal Manajemen Dakwah, 3(01), 84-104.

Noor, M. U. (2018). Penilaian kualitas informasi sebagai bentuk sikap tabayyun ketika menerima informasi di sosial media dan internet. BIBLIOTIKA: Jurnal Kajian Perpustakaan dan Informasi, 2(1), 33-40.

Nurrahman, A. (2020). PERAN PEMERINTAH DAERAH DALAM MEMELIHARA KETENTERAMAN DAN KETERTIBAN UMUM (STUDI PADA PENANGANAN PENYEBARAN VIRUS COVID-19 DI PROVINSI DKI JAKARTA). Jurnal Tatapamong, 1-16.

Prasetya, A. (2020). PENGALAMAN PEKERJA INFORMAL DITENGAH PANDEMI COVID19 DI KOTA BANDUNG. Jurnal Komunikasi, Masyarakat dan Keamanan, 2(2).

Putri, A. (2020). Penyakit Menular (andriany Putri X MIA 3).

Rayani, D., \& Purqoti, D. N. S. (2020). Kecemasan Keluarga Lansia terhadap Berita Hoax Dimasa Pandemi Covid-19. Realita: Jurnal Bimbingan dan Konseling, 5(1).

Sainuddin, I. H., S. (2020, August 7). Aktivitas Dakwah di Masa New Normal. https://doi.org/10.31219/osf.io/dejy2

Sainuddin, I. H., S. (2020, July 19). Transformasi Dakwah di Masa Pandemi Covid-19. https://doi.org/10.31219/osf.io/nakhy

Setyawati, N. (2020). IMPLEMENTASI SANKSI PIDANA BAGI MASYARAKAT YANG BERAKTIVITAS DI LUAR RUMAH SAAT TERJADINYA PANDEMI COVID19. JURNAL EDUCATION AND DEVELOPMENT, 8(2), 135-135.

Siti Maryam, N. (2017). Mewujudkan good governance melalui pelayanan publik. JIPSI-Jurnal Ilmu Politik dan Komunikasi UNIKOM, 6.

Supriatna, E. (2020). Wabah Corona Virus Disease COVID-19 Dalam Pandangan Islam. Jurnal Sosial \& Budaya, 7(6), 555-564.

Supriatna, E. (2020). Wabah Corona Virus Disease COVID-19 Dalam Pandangan Islam. Jurnal Sosial \& Budaya, 7(6), 555-564. 
Susanto, N. (2020). Pengaruh Virus Covid 19 Terhadap Bidang Olahraga Di Indonesia. Jurnal Stamina, 3(3), 145-153.

Syaipudin, L. (2020). Peran Komunikasi Massa di Tengah Pandemi Covid-19 (Studi Kasus di Gugus Tugas Percepatan Penanganan Covid-19 Kabupaten Tulungagung). Kalijaga Journal of Communication, 2(1), 14-34.

Yunus, N. R., \& Rezki, A. (2020). Kebijakan Pemberlakuan Lock Down Sebagai Antisipasi Penyebaran Corona Virus Covid-19. Salam: Jurnal Sosial dan Budaya Syar-i, 7(3), 227238. 